\begin{tabular}{l} 
RCCS \\
\hline Annual Review
\end{tabular}

\section{RCCS Annual Review}

A selection from the Portuguese journal Revista Crítica de Ciências Sociais

$2 \mid 2010$

Issue no. 2

\title{
The Sexual Trafficking of Women: Representations of Illegality and Victimisation
}

\section{Boaventura de Sousa Santos, Conceição Gomes and Madalena Duarte}

Translator. Sheena Caldwell

\section{(2) OpenEdition}

\section{Journals}

Electronic version

URL: http://journals.openedition.org/rccsar/247

DOI: $10.4000 /$ rccsar.247

ISSN: $1647-3175$

Publisher

Centro de Estudos Sociais da Universidade de Coimbra

\section{ELECTRONIC REFERENCE}

Boaventura de Sousa Santos, Conceição Gomes and Madalena Duarte, « The Sexual Trafficking of Women: Representations of Illegality and Victimisation", RCCS Annual Review [Online], 2 | 2010, Online since 01 October 2010, connection on 19 April 2019. URL : http://journals.openedition.org/rccsar/247 ; DOI : 10.4000/rccsar.247 


\section{Boaventura de Sousa Santos}

School of Economics and Centre for Social Studies, University of Coimbra, Portugal

\section{Conceição Gomes}

Centre for Social Studies, University of Coimbra, Portugal

Madalena Duarte

Centre for Social Studies, University of Coimbra, Portugal

\section{The Sexual Trafficking of Women: Representations of Illegality and Victimisation*}

Human trafficking in general and the trafficking of women in particular have been attracting increasing interest from states, international bodies, non-governmental organisations, the media and academia. The greater visibility conferred on this phenomenon has translated, on a national and international level, into policies designed to combat and prevent it, whose efficiency is debateable. This is the result not only of a lack of understanding of the specific features of the trafficking of women, but also of the fact that other objectives underlying the construction of these policies hardly meet the subjective needs and expectations of trafficked women. This article discusses some of the issues both emerging and absent from the legal framework for the sexual trafficking of women, with reference to the empirical situation of sexual trafficking in Portugal as analysed in the study Tráfico de mulheres em Portugal para fins de exploração sexual. ${ }^{1}$

Keywords: Organized crime; women's rights; women's studies; feminism; sex industry; prostitution; trafficking of women; human trafficking; violation of human rights.

\section{Introduction}

The world today operates on deeply drawn lines which separate the human from the subhuman world, in such a way that human principles are not threatened by inhumane practices. Thus, on the other side of the line we find a space which is a non-territory in legal and political terms, a space unthinkable in terms of the rule of law, human rights and democracy (Santos, 2007). Essentially, we find people who do not exist, either in social or legal terms. These spaces are constructed on the basis of new forms of slavery, the illegal trafficking of human organs, child labour and the exploitation of prostitution.

During the past decade the problem of human trafficking, although not new, has been the subject of reinforced legislation designed to combat it. This includes, in particular, criminalisation of the phenomenon and its active agents, and enhanced rights and support for its victims. Whilst, for some, this is the most appropriate direction to follow, others feel

\footnotetext{
* Article published in RCCS 87 (December 2009).

${ }^{1}$ This article closely follows the theroretical considerations and empirical data contained in the book Tráfico de mulheres em Portugal para fins de exploração sexual (The Trafficking of Women in Portugal for the Purposes of Sexual Exploitation), by Boaventura de Sousa Santos, Conceição Gomes, Madalena Duarte and Maria Ioannis Baganha (2008).
} 
that other aspects should be taken into consideration in order to make these measures and protection truly effective. Firstly, the initiatives and political strategies designed to combat trafficking, in particular sex trafficking, have not met with any consensus on a definition of this specific type of trafficking. In fact, competing definitions can easily be found and there is little agreement among researchers and activists. Broader or more restricted definitions of the concept of sex trafficking influence, from the outset, the figures that are presented and, subsequently, the measures designed to combat it. It is difficult to find solid and reliable figures for sex trafficking, whether on a national, continental or worldwide level, and this has led to two extreme positions which, as such, can effectively do little to help trafficked women. Each international organisation presents us with figures that may vary by thousands or even millions. Some refer to very high numbers, whilst others contest this and believe that sex trafficking is a minor phenomenon. Both positions contain dangers. The first runs the risk of denying women's self-determination, assuming that trafficking exists in situations of aid to illegal immigration or voluntary prostitution. The second runs the risk of not helping women who really are in danger.

Secondly, human trafficking brings with it issues that cannot be ignored when formulating a legislative response: the control of state borders, the fight against terrorism and the way in which each country deals with prostitution. As some authors argue (e.g. Kempadoo, 2005a), the fight against human trafficking may have different impacts in different countries in the global North and South.

These two aspects converge, particularly in what concerns the arena legal, in the form of a significant discrepancy between what is prescribed in legislation and its practical application, which is full of stereotypes and preconceptions. The law, understood here as both the text of the law and judicial practice, is therefore faced with major obstacles in terms of the role it can and/or could play in the fight against human trafficking.

\section{Sex trafficking in context}

Sex trafficking is far from being an isolated problem. Its causes are intrinsically linked to other social, economic, political and cultural phenomena, meaning that in several cases it does not just involve a violation of rights resulting from trafficking.

Slavery, a social practice which granted rights of ownership to one human being over another, was common throughout the world in antiquity. The intercontinental slave trade 
began with European expansion and the creation of the world system at the end of the 15th century, with the seafaring voyages of Portugal and Castile, in what some authors have called the first modernity (see Mignolo, 2000). The trafficking of individuals via the slave trade across the Atlantic therefore enters history, as Paul Gilroy argues in The Black Atlantic (1992), as an economic and migratory flow that was an integral part of modernity. Nowadays, the prominence of human trafficking shows that the abolition of slavery in various countries has not put an end to the plague of human trafficking, nor the place it occupies in modern economic and migratory routes.

When we consider human trafficking and the way in which this phenomenon has gained importance, we also find transnational flows which follow the logic of economic gain without any respect for the self-determination of individuals. Although it is true that this illegal, informal phenomenon run by criminal organisations has a completely different role from that of slavery, which was central to the formation of the world system, it is still inextricably related to it. The point is that, whilst the practices of trafficking are not central to the global transnational markets or the global world in which we live, as slavery once was, they are nevertheless embedded in the inequalities and injustices of the distribution of wealth promoted and encouraged by the world system. Thus, although colonialism and the legitimate trading of individuals between countries have ended, the profound inequalities between North and South are nowadays the driving force behind a clandestine logic that leads to subhumanity (Santos, 2007).

The Marxist concept of the "primitive accumulation of capital" helps us to understand better the emergence of this subhumanity, of which human trafficking is such a singular expression. For Marx, one of the conditions of capitalist wealth was the exploitation of labour. Although it is based on the idea of free labour, capitalism, in fact, has a tendency to use not only labour but also space, the surrounding environment and nature in a destructive way. Capital tends to weaken or destroy its own conditions of production, since the constant crises caused by increased costs always lead to new attempts to restructure the conditions of production in order to reduce costs. These conditions imply that everything should be treated as a commodity, including labour. These characteristics of capitalism were very evident in its early days, when the accumulation of wealth presupposed, as already stated, slavery, pillage and colonisation. However, these forms of over-exploitation are not only confined to one phase of capitalism. Capitalist societies worldwide always need these and 
other forms of over-exploitation in order to maintain capital in the form that we know it. With the advent of neoliberal globalisation this has become even more evident.

There are at least three aspects of neoliberal globalisation which, although not promoting human trafficking, make its restriction more difficult: the creation of a privatised global economy with residual state control, in which local markets become interlinked; the liberalisation of trade, involving the weakening of borders for the circulation of people, goods and services that serve to create this global market; and the spread of production via foreign investment in multinationals. With specific regard to the trafficking of women for the purposes of sexual exploitation, this has meant that, with less state control, a global sex industry has developed in which a particular group of people, namely women, are repeatedly exploited. This is facilitated by a form of circulation in which people from the poorer countries migrate to work in this industry, voluntarily or against their will, and those from the rich countries travel for recreational and sex tourism, which is also fuelled by foreign investment (Farr, 2005: 140-141). Obviously the logic and dynamics of selfdetermination and even emancipation that are involved in the sex industry but evade the web of trafficking also need to be taken into consideration.

With the establishment of neoliberal globalisation from the 1980s onwards, we have been witnessing the desocialisation of capital, meaning that social rights can no longer be guaranteed, thus contributing towards the increased vulnerability of millions of people throughout the world. During the $20^{\text {th }}$ century the creation of wealth was subject to a series of state and non-state regulations which allowed for some redistribution of wealth and the creation of secure conditions for the populations who did not possess wealth, specifically social and economic rights such as unemployment benefits, public health, education, social security, etc. Social redistribution measures were essential in creating a safety net to alleviate social risk, preventing individuals from falling into deep poverty. This net has nowadays been weakened to such an extent that, when faced with unemployment, even the middle classes find themselves in need of assistance. In a situation in which the regulations created at national level fail, capitalism as a form of global economic organisation remains in a more comfortable position from which to pursue its goals, with consequences that are increasingly evident. We shall highlight two of these.

The first concerns the great weakness of the system itself, evident in the economic and financial crises recently experienced, of which the collapse of major US companies is a 
paradigmatic example. In order to prevent economic collapse, the state has supported these investors through taxation, to the extent of virtually creating a welfare state for capital, when it does not exist for citizens. This means that even in the richest country in the world, people are more vulnerable.

The second consequence is precisely the perception that the primitive accumulation of capital is an ongoing condition, as previously suggested. In various countries in different continents we are beginning to encounter forms of slave labour and over-exploitation of the labour force which are dragging certain groups of people into non-human conditions. If we look back at history, we can see that Indians, indigenous populations and women, amongst other groups, fell into this category, to which, nowadays, many immigrants can be added. These people are not only illegal, but actually have no existence, from a legal point of view.

In our view, the trafficking of women for the purposes of sexual exploitation should be understood, initially, from this perspective. There are women who are forced to work as prostitutes (against their will), and also situations in which female prostitutes are forced to work under conditions which they cannot choose. However, the new element which capitalism has added to slavery is that workers are free to sell their labour. Therefore, according to certain views, women should be free to sell their sexual availability as labour. This position is not consensual, as we shall see later. However, in the forms of overexploitation we are aware of, of which sexual trafficking is one example, women who sell their sexual availability as labour are also forced to sell not only their availability, but their freedom and identity as well.

Within this context of over-exploitation in the labour market, various authors (e.g. Ehrenreich and Hochschild, 2002) argue that any policy designed to fight human trafficking must extend beyond criminalising traffickers to reinforce the rights of immigrants and workers. In the specific case of the trafficking of women for the purposes of sexual exploitation, various authors also argue that prostitution must be included in the legalnormative framework of each country. However, there are various interpretations of the course the law should follow in this area: whilst some opinions veer towards criminalising prostitution (e.g. Barry, 1995), others demand that prostitution be regulated as a form of employment (e.g. Kempandoo, 2005b). This topic will be developed in the next section. 


\section{The social construction of the "victim": Stereotypes and preconceptions}

Within feminist studies, the definition of "victim" is complex and the concept is often rejected, as it presupposes the passivity of women vis-à-vis the structures that oppress them, namely patriarchy. Sex trafficking makes the concept more complex by raising questions that ultimately transcend it, namely ethical questions about society itself. These questions are embedded in the consciousness and ethical paradigms by which we are regulated, some of which are social taboos. Societies are "the image they have of themselves, reflected in the mirrors they construct to reproduce dominant identifications at any given time in history" (Santos, 2000: 45). It is these mirrors that allow routines to be created to ensure the functioning of society. One of these mirrors is undoubtedly the law i.e. laws, norms and legal and judicial institutions - which not only reflects society but also guarantees that it functions. Thus we encounter, both in the legislation relating to trafficking and in its application, stereotypes and preconceptions that merit consideration.

Rather than adopting an exhaustive approach, we shall analyse two key issues from the empirical data gathered as part of the study Tráfico de mulheres em Portugal para fins de exploração sexual (Santos et al., 2008) as crucial for the identification of trafficking situations.

\subsection{Immigrant women: From invisibility to demonisation}

In recent years the visibility of migrant women has increased, although not always for the best of reasons. Female circumcision, the use of the veil in French schools, polygamy and prostitution have entered the political discourse of many Western countries, controversially revealing the presence of migrant women. Far from serving as a basis for an in-depth reflection on the integration of migrant women or multiculturalism, these issues have been used as a pretext for once again viewing elements of the culture and religion of immigrants as disturbing. Migrant women have now changed from being invisible to being demonised and instrumentalised (Gaspard, 1998). Thus, whether due to their invisibility or their demonisation, migrant women have become particularly vulnerable to falling into the hands of networks of traffickers who exploit them and violate their dignity. The fact that they have no visibility with regard to the specific nature and complexity of their situations also favours negligent reception policies. 
For some authors, the trafficking of women should therefore be considered within this context. According to Joanna Regulska (1998), the increase in flows of migrants from Central and Eastern Europe to Western European countries has led to the need for the latter to reinvent themselves and begin to construct "others" who are no longer from other continents but from Europe itself, subjecting them to selective processes of inclusion or exclusion. They are no longer the qualified migrants who benefit Western Europe, but now include undesirables who add to the rise in crime. In this changing discourse, women from Central and Eastern Europe become "other European women," whose influx becomes undesirable and disturbing. Thus, whilst admitting that the trafficking of women in these regions is a major and serious problem, the author questions the almost sudden emergence of this phenomenon.

In our study Tráfico sexual em Portugal para fins de exploração sexual we identified some of these trends, particularly through an analysis of the press that focused on the connection between Eastern European immigrants and organised crime, including the trafficking of women. The perception of this connection by public opinion is somewhat curious, since most of the interviewees believed that the crime of sexual trafficking in Portugal is nowadays essentially carried out by groups with a far less "heavyweight" and almost unsophisticated structure, and less by groups such as the Eastern mafias who were active in Portugal at the end of the 1990s and the beginning of $2000 .^{2}$ In addition, the available information indicates that, as a rule, Portuguese citizens are involved in these networks, in most cases assuming the role of owners of establishments or coordinators of the work and resulting profits, and also feature in other areas, such as security, transport (for example as drivers or even taxi drivers). Foreigners are essentially the recruiters, carriers and sometimes the controllers of the women.

We also identified the construction of a negative visibility for immigrant women, in particular Brazilian women.

Various studies indicate that there is an increasing incidence of foreign citizens involved in prostitution in Portugal. This is evident from the study carried out by Manuela Ribeiro et al.

\footnotetext{
${ }^{2}$ In the opinion of the interviewees, the lower profile of these groups in Portugal is primarily due to the efforts of the criminal police, at the beginning of 2000, to eradicate the Easter European mafias that were operating in Portugal and were linked to trafficking, extortion, falsification of documents, murders, kidnappings, abductions, etc. Police action led to various sentences and deportations.
} 
(2005) on prostitution in clubs, ${ }^{3}$ which concludes that women who work as prostitutes in clubs and hostess bars come primarily from Latin America, specifically from Brazil (62\%) and Colombia (8\%). This also appears to be the view of certain civil society organisations interviewed by us, who work directly with female prostitutes. This view is related to the dissemination of a stereotype of the Brazilian woman associated with pleasure and sensuality (Téchio, 2006), to which may be added ease of communication due to language similarities, which increases their demand in the sex industry.

In emerging as one of the main nationalities involved in the "sex market" in Portugal, many Brazilian women are linked to processes of social exclusion and precarious lifestyles which obviously may, at any given moment, lead to situations of sex trafficking. Two risks emerge from this. Firstly, the fact that prostitution involving Brazilian women is overwhelmingly viewed as a "migrant work" choice may mean that situations involving exploitation and trafficking are ignored. In addition, the number of Brazilian women working as prostitutes also leads to a process in which the stigma of prostitution is "passed on" to other immigrants of the same nationality:

I think that the link between prostitution and immigrant communities only came about because immigration became a topic for debate in society, and from then onwards certain stereotypes were created and one of those that I can see has been created, a negative one, is to associate immigrant women, particularly those from certain countries, with prostitution. [...] We, as an association which protects immigrants, cannot admit that women from our own country are seen as prostitutes, which is the intention with regard to Brazilian women. From the moment they arrive at the airport, the treatment they receive on entry is different. We have acquired the idea of a certain profile. (E7, non-governmental organisation) ${ }^{4}$

The "Mães de Bragança" movement ${ }^{5}$ has contributed to this, and the high profile media coverage of this case helped to awaken Portuguese society to a moralism that has been used to demonise Brazilian women in Portugal. This is a key question in the identification of trafficking situations and the social construction of "good victims," as opposed to "bad victims."

\footnotetext{
${ }^{3}$ The study covered a sample of 142 women, 120 of whom were foreign citizens.

${ }^{4}$ Quoted from an interview transcribed in the study Tráfico de mulheres em Portugal para fins de exploração sexual (2008).

${ }^{5}$ This was a movement organized in 2003 by a group of women from the city of Bragança, in northeast Portugal, with the aim of driving Brazilian women working in clubs or as prostitutes out of town. [T.N.]
} 


\subsection{Sex trafficking and prostitution: The central issue of consent}

If a woman's consent to emigrate not infrequently makes the legal identification of trafficking less clear, this becomes even more complex when this migratory strategy includes an independent decision to work as a prostitute in the host country. The relationship between prostitution and trafficking and the distinction, where it exists, between enforced and voluntary prostitution are controversial matters which require a brief historical contextualisation.

Concerns over the trafficking of women began in the late $19^{\text {th }}$ century and early $20^{\text {th }}$ century with anxieties over the migration of individual women and the capture and enslavement of women for prostitution. In the $19^{\text {th }}$ century, the intensification of female migration as an independent and self-determined strategy soon created a certain fear of the immorality that might be introduced into Western countries, specifically due to the perception that women had migrated to work as prostitutes. This led to a racially and sexually based panic that gave rise to the fear of white slave trafficking. This is not to deny the fact that women were effectively being trafficked or exploited, but rather to attempt to contextualize the discourse of trafficking and the emergence of policies to combat this, emerging out of a fear of the non-Western, criminal, violent "other" who brutalised and violated them. These concerns led to the creation of the International Convention for the Suppression of Traffic in Persons and the Exploitation of the Prostitution of Others, approved by the General Assembly of the United Nations Resolution 317(IV) of 2 December 1949, and concluded at Lake Success in New York on 21 March $1950 .^{6}$

Accordingly, states that were parties to the Convention agreed to punish any individual who, to gratify the passions of another, procured, enticed or led away another person for the purposes of prostitution. The exploitation of prostitution was punishable, and consent to these practices irrelevant.

For some states ratification was problematic due to the tensions it created with certain provisions in their own national legislation, particularly with regard to prostitution. Some governments believed that, although the Convention did not directly criminalise prostitution, it contained certain provisions that appeared to point in this direction, thus contradicting provisions on prostitution contained in national legislation. It was also argued

\footnotetext{
${ }^{6}$ Ratified in Portugal by Presidential Decree no. 48/91 of 10 October.
} 
that the clauses in the Convention did not make a clear distinction between voluntary and forced prostitution.

This preoccupation with sexual trafficking remained during the years that followed. It was in the 1980s that the feminist movement began to wake up to the question of international trafficking and prostitution, although without reaching a consensus on the matter. On the one hand, there are the "abolitionist feminists" who consider that prostitution reduces women to objects to be purchased and is always a form of sexual exploitation. Kathleen Barry (1995), one of the founders of the Coalition Against Trafficking in Women (CATW) and one of the most active voices on this front, argues that sexual exploitation is a political condition and the basis of the subordination of and discrimination against women and the perpetuation of patriarchy. Sheila Jeffreys believes that a woman's willingness to engage in prostitution is politically and socially constructed on the basis of poverty, sexual abuse and women's family obligations (1999: 180). Those who support this position make no distinction between enforced and voluntary prostitution and consider that any concession by the state towards legalisation is essentially a concession to constant violations of human rights, dignity and sexual autonomy. As trafficking is closely linked to prostitution, abolitionist feminists argue that the former is more easily fought by fighting prostitution and believe that the path followed by various states, including Holland and Germany, which involves establishing a distinction between trafficking and prostitution, is dangerous. In their view, by legalising prostitution the message that states are sending out to women is that, within a context of culturally acceptable patriarchal practices, when all other opportunities have run out society will provide them with another which they should not refuse, namely selling their own body.

At the start of the 1990s this position was the target of countless critiques, both by the transnational feminist movement and the sex workers movement. The latter does not see prostitution as an essentially degrading activity or as an instance of the extreme sexual oppression of women, but rather as an activity that reflects the right of women to control their own bodies, which includes providing sexual services. They therefore argue that prostitution is a job that should have a legally established framework so that the rights of sex workers, who are not necessarily only those who practice prostitution, can be respected. They believe that the relationship between trafficking and prostitution is often invoked to block the legalisation of prostitution and the establishment of sex workers' rights: "What this 
discourse does not let us hear are the voices of those who choose to emigrate to work in the sex industry, those who, although they do not have the best of living and working conditions, are far from identifying themselves as victims or living as slaves" (Lopes, 2006: 43).

This critique is voiced by authors such as Kamala Kempadoo and Jo Doezema (1998), who have studied these questions from a Southern perspective. According to them, the abolitionist feminists have created an image of the woman from the South as the eternal submissive who is ignorant, bound by traditional cultural concepts and victimised, whilst Western women emerge as the civilized saviours. In our understanding, this is not to deny that sex trafficking exists as a form of violence against women, but to demand that multiple perspectives be taken into account when considering the phenomenon. Sex trafficking cannot be understood as a one-dimensional interpretation based on gender and the oppression of women by patriarchy, since the complexity of the actual sex industry evades this analysis. Trafficking emerges not only from patriarchal relationships but also from state, capitalist, imperialist and racial power (Kempadoo, 2005a: 61), since all converge in the sex market. Moreover, these are variables that have made feminist studies enter into a dialogue with other theories. This is why we are increasingly seeing variables such as race, religion or sexual orientation being taken into consideration in studies on domestic violence against women, for example. For these authors, however, analyses of sex trafficking persist in maintaining a closed dialogue, influenced by a conservative view of prostitution as a form of violence against women in an industry - the sex industry - created and managed by men, in which women have no autonomy or power to act. Yet, if women's power to act is recognised in other analyses of patriarchy, why not in sex trafficking?

According to these perspectives, it is essential to listen to the woman's views concerning her wishes and expectations and to understand the aspects and dynamics of how she sees herself as a victim or as an agent, whilst avoiding any logic of criminalisation (Kempadoo, 2005b; Kapur, 2005). This view is particularly important when a Southern epistemology is introduced into the analysis, forcing us to take into account the strategies of women who, due to various factors (economic, cultural, the consequences of war, etc.), decide to emigrate to another country to work in the sex industry. From a post-colonial perspective, these authors therefore point out that attention should be paid to women from the South so that their interests can be understood and the social relations in which they engage are not constantly seen as archaic and authoritarian. Their consent is a central issue here, and their 
voice, migration choices and survival strategies should be taken into account. Some of these women are migrant workers and not sex slaves; they want security but do not want to be saved (Kempadoo, 2005b).

In accordance with these arguments, a clear distinction must therefore be established between voluntary and forced prostitution and between adult and child prostitution within the context of the fight against sex trafficking, and the sex industry should not be equated with trafficking. This is the understanding of the Global Alliance Against Trafficking in Women (GAATW), which has emerged, together with the CATW, as an important transnational NGO in the fight against trafficking, but is positioned on this side of the debate (see Pickup, 1998 and Sullivan, 2003).

The debate summarised here had implications on the drafting of the United Nations Additional Protocol to Prevent, Suppress and Punish Trafficking in Persons, especially Women and Children, known as the Palermo Protocol. ${ }^{7}$ Whilst the Protocol tends to be unanimous in terms of definition, it does not assume any stance on the relationship between trafficking and prostitution, nor does it clearly define the terms "sexual exploitation" and "prostitution."

During the negotiations for the Protocol it was quickly agreed that enforced prostitution came under the proposed definition of trafficking, but there was intense discussion on whether prostitution in general should be included (Engle, 2004: 58). Sweden, for example, criminalises procurement and punishes clients who resort to sexual services provided by trafficked women, whilst the German and Dutch governments have decriminalised prostitution and established rules to regulate employment in this area. Due to this diversity of legal situations, the Protocol does not clarify this controversial issue but leaves it as a matter for individual states to decide.

As a consequence, the two sides of the debate have different interpretations of the text of the Protocol. The CATW states that it agrees with the beliefs expressed in the 1949

\footnotetext{
7 In 2000, the General Assembly of the United Nations adopted the Convention against Transnational Organised Crime, which contained two separate Protocols: the Additional Protocol to Prevent, Suppress and Punish Trafficking in Persons, Especially Women and Children and the Additional Protocol against the Smuggling of Migrants by Land, Air and Sea, including two definitions of human trafficking and smuggling. Trafficking in persons is defined in the Protocol as "the recruitment, transportation, transfer, harbouring or receipt of persons, by means of the threat or use of force or other forms of coercion, of abduction, of fraud, of deceit, of the abuse of power or of a position of vulnerability or the giving or receiving of payments or benefits to achieve the consent of a person having control over another person, for the purpose of exploitation. Exploitation shall include, at a minimum, the exploitation of the prostitution of others or other forms of sexual exploitation, forced labour or services, slavery or practices similar to slavery, servitude or the removal of organs."
} 
Convention on Trafficking, namely that prostitution and trafficking are incompatible with human dignity and that consent to trafficking for the purposes of sexual exploitation is impossible, whilst the GAATW considers that the Protocol only covers enforced prostitution and does not demand that governments treat all prostitution as trafficking.

\section{The situation in Portugal}

The trafficking of human beings is, as a rule, a very clandestine, closed and complex phenomenon, for which it is difficult to calculate the real numbers of people involved. In 2008 a model was introduced to signal, identify and integrate individuals involved in trafficking situations, which appears to have made an important contribution towards a more informed understanding of the quantitative reality of human trafficking in Portugal. According to a joint statement issued by the Coordinator and National Rapporteur for Human Trafficking and the team leader of the Observatory for Human Trafficking, by June 2009 the monitoring system had accounted for a total of 231 cases of possible human trafficking situations (46 signalled in the first 6 months of 2009, and the remainder the result of signalling during the previous year). Some of these cases were still then under investigation in order to confirm whether or not they involved situations of trafficking. Whatever the case may be, it can be said that by June 2009, 41 cases out of the 231 registered (18\%) had been confirmed. One aspect of the situation seems to stand out in particular: the overwhelming majority of the alleged victims were foreigners, particularly Brazilians (above all when sexual exploitation was involved). The situation of illegal status was common to two thirds of the foreign individuals signalled, reinforcing the idea that illegality contributes to the vulnerability of many immigrants, placing them in situations that favour various kinds of exploitation (Santos et al., 2008). It is particularly significant that, even though the cases signalled refer mainly to sexual exploitation, the majority of those already confirmed are associated with exploitation of labour and involve male victims. This fact may represent the reality, but it may also be the result of the greater complexity involved in detecting and confirming sex trafficking. 


\subsection{Sex trafficking as a crime ${ }^{8}$}

The crime of human trafficking has existed in the Portuguese legal system since 1982 . The 1982 Penal Code (approved by Decree-Law 400/82 of 23 September) established in Article 217(1) that "whomsoever is involved in human trafficking by procuring, enticing or leading another, even with their consent, into practising prostitution in another country or any acts contrary to decency or sexual morality shall be punished by a term of imprisonment of 2 to 8 years and a fine payable within 200 days." The aim of the law was to protect not only the personal interests of the victims, but also a set of interests common to the whole of society. It should also be noted that the reference made in this Article to "prostitution" and to "acts contrary to decency or sexual morality" and their systematic insertion in the Penal Code ${ }^{9}$ reflected a greater concern with protecting social values than with the individual interests of the victims.

Decree-Law 48/95 of 15 March amended the Penal Code, introducing relevant changes in this area. One of the main changes was that the protection of individual interests took priority over the protection of the moral values of society. This change in the philosophy of the law emerged from the outset in Point 1 of the Preamble to the legislation in the consideration that "the increasingly universal trend towards affirming human rights as a fundamental principle in modern societies, in addition to the reinforcement of the ethical dimension of the state, establishes justice as the first guarantor of the consolidation of the fundamental values recognised by the community, with a special emphasis on human dignity."

The same objective of reinforcing supervision of personal legal interests led the legislator to make changes to the system itself, namely the "removal of sex crimes from the chapter on crimes against the values and interests of society to the title on crimes against individuals, forming a separate chapter entitled 'Crimes against liberty and sexual selfdetermination,' and abandoning the moralistic concept ('general moral sentiments') in favour of liberty and sexual self-determination, eminently personal interests." ${ }^{10}$ Thus the

\footnotetext{
${ }^{8}$ Due to limited space we present here only a brief summary of the evolution of this legal precept. See Santos et al. (2008) for a more detailed analysis.

${ }^{9}$ In Section II - Sex crimes - of Chapter I - Crimes against the ethical and social basis of society - of Title III Crimes against the values and interests of society.

${ }^{10}$ In addition to this systemic alteration, the Decree-Law amended the requisites for the legally defined crime of human trafficking, which was moved to Article 169 of the Penal Code. The law stipulated that "whomsover, by means of violence, serious threats, deception or fraudulent schemes, leads another person into engaging in
} 
legal interest that was protected became the individual freedom of sexual selfdetermination. It should be stressed, however, that the goal was not to punish the practice of prostitution itself, but the conduct of agents who, by deceptive or violent means, involved individuals in prostitution or other defined sexual acts in a foreign country. ${ }^{11}$ In other words, the agent would not be punished if the individual had consented to engage in prostitution or other defined sexual acts in a foreign country knowingly and of their own informed, free will, without the imposition of any conditions or constraints by the agent who brought them to the said country.

The reform of the Penal Code under Law no. 65/98 of 2 September extended the scope of application of the regulations which stipulated the legally defined types of human trafficking (Article 169) and pimping (Article 170), eliminating one element stipulated in the previous Code - "exploitation of situations of neglect or need."

With regard to the crime of human trafficking and pimping, and with the aim of making effective in practice the provisions contained in the Additional Protocol to the Palermo Convention, Law no. 99/2001 of 25 August amended Articles $169^{12}$ and $170(2)^{13}$ of the Penal Code, extending the provisions in law for these types of crime. The law added the following objective elements: abuse of authority resulting from a hierarchical, economic or employment relationship in which the victim is a dependent, and profiting from any particularly vulnerable circumstances affecting the victim.

According to the preparatory work for the Palermo Convention, abuse of a vulnerable situation is understood to occur whenever "the individual targeted has no other real or acceptable choice than to submit to abuse." This concept of "abuse of a vulnerable

prostitution or other defined sexual acts abroad, exploiting a situation of neglect or need, shall be punished by a term of imprisonment of 2 to 8 years."

${ }^{11}$ The conduct of the agent who corrupts the will of another person prepared to travel abroad may therefore take the form of violence or serious threats, on the one hand, or deception and fraud. Violence and serious threats occur when the victim has no chance to express his/her own wishes and may be the target of physical or psychological violence. In employing deception or fraud, the agent tricks the victim (by offering employment in a restaurant, for example), leading him/her to make an erroneous decision concerning his/her wishes which s/he would not have made if the true situation had been known (see Rodrigues, 1999).

12 "Whomsoever, by means of violence, serious threats, deception, fraudulent schemes, abuse of authority resulting from a hierarchical, economic or employment relationship in which the victim is a dependent, or by taking advantage of any situation of particular vulnerability, entices, transports, harbours or receives another person, or provides the conditions for this person to engage in prostitution or other defined sexual acts abroad shall be punished by a term of imprisonment of 2 to 8 years."

13 "If the agent uses violence, serious threats, deception, fraudulent schemes, abuse of authority resulting from a hierarchical, economic or employment relationship in which the victim is a dependent or takes advantage of the psychological incapacity of the victim or any other situation of particular vulnerability, s/he shall be punished with a term of imprisonment of 1 to 8 years." 
situation" is a concept which still causes a great deal of controversy in terms of its practical application. Moreover, the fact that few cases of human trafficking for the purposes of sexual exploitation have been brought to court limits the debate in terms of jurisprudence and deeper examination of the concept.

Law no 59/2007 of 4 September introduced amendments relating to the trafficking of women for the purposes of sexual exploitation. Some of the amendments were imposed by European Union framework decisions and other instruments binding upon the Portuguese state. ${ }^{14}$ It should be noted, first of all, that the change in classification reflects the seriousness of this type of crime. The crime of human trafficking no longer appeared in the section of the Penal Code referring to crimes against sexual freedom, but was moved to the chapter on crimes against personal freedom.

Within a new context of increasing and more visible criminal phenomena associated with human trafficking and pimping, this legislative revision stipulated a significant alteration with regard to these types of crimes, reformulating the crime of human trafficking, now related to activities of sexual exploitation, exploitation of labour and the extraction of organs. In accordance with the new law, individuals who "offer, deliver, entice, accept, transport, harbour or receive persons" for these purposes, either "by violence, kidnapping or extreme threats," "deception or fraudulent acts," or "by abusing the authority resulting from a hierarchical, economic, employment or family relationship in which the victim is a dependent" will be punished. Agents will also be punished for practising these acts, whether professionally with lucrative intentions or by taking advantage of the "psychological incapacity or any vulnerability associated with the victim, or by obtaining the consent of the person who has control over the victim."

With regard to pimping, Law no. 59/2007 of 4 September removed the concept of defined sexual acts from the legal precept. According to the new precept, an agent who, "professionally or with lucrative intentions, encourages, promotes or facilities the engagement of another in prostitution shall be punished with a term of imprisonment of 6

\footnotetext{
${ }^{14}$ In particular, the United Nations Convention against Transnational Organised Crime and the Additional Protocol to Prevent, Suppress and Punish Trafficking in Persons, especially Women and Children, approved by Assembly of the Republic Resolution no. 32/2004 of 2 April and ratified by Presidential Decree no. 19/2004 of 2 April; Council Framework Decision 2002/629/JAl of 19 July 2002 on preventing and combating trafficking in human beings; Council Framework Decision 2004/68/JAI of 22 December 2003 on combating the sexual exploitation of children and child pornography; and the Council of Europe Convention on Action against Trafficking in Human Beings signed by Portugal on 16 May 2005.
} 
months to 5 years. An agent who commits the crime of pimping, either by using violence or extreme threats, deception or fraudulent acts or by abusing the authority resulting from a family, supervisory or guardian relationship, a dependent hierarchical, economic or employment relationship, or by taking advantage of the psychological incapacity or any vulnerability associated with the victim, shall be punished with a term of imprisonment of 1 to 8 years."

As already mentioned, concepts inscribed in the text of the law, such as "vulnerability," may give rise to certain practical difficulties in identifying individuals in a trafficking situation, and it is therefore necessary to "pave the way" for the task of interpretation. For Pedro Vaz Patto (2007), the "elasticity" and scope of this concept leads to the presupposition, for example, that almost all situations leading to prostitution are linked to extreme poverty. In addition, according to Vaz Patto, the question of consent assumes particular relevance here, especially for those who are on opposite sides of the debate concerning the legalisation of prostitution. Although he emphasizes that these are separate issues, he argues that the fact that consent is considered irrelevant in situations where vulnerability is exploited may, in practice, come close to criminalising prostitution in general, the reverse being equally possible. These questions are extremely important in terms of the legal construction of the "victim."

\subsection{Representations of the "victim" in sexual trafficking in Portugal}

Most sources consulted ${ }^{15}$ in the aforementioned study indicate the prevalence in Portugal of women who gave their initial consent to work in prostitution or, at least, in the sex industry, and later found themselves in situations in which they were exploited and their autonomy was severely restricted. However, we also encountered cases, either reported by interviewees or through analyses of legal proceedings, in which women did not know that the work awaiting them in Portugal was prostitution.

According to the experiences of many of the interviewees, the majority of Brazilian women who ended up involved in trafficking, as defined in law, initially gave their consent to work in prostitution as a migratory strategy, but later found themselves in situations in which they were heavily exploited. Extreme cases of deception - in which the woman did not know she would be forced to work as a prostitute or in any other activity of a sexual

\footnotetext{
${ }^{15}$ The study methodology should be consulted for more information on these sources (Santos et al., 2008).
} 
nature - involve primarily women of other nationalities, in particular those from Central and Eastern Europe, Asia and Africa. This perception merits various considerations.

Whilst admitting that this interpretation may reflect reality, we should still bear two factors in mind. Firstly, it should be noted that it was through violent cases involving women from Eastern Europe that Portugal woke up to the reality of this kind of trafficking. In fact, according to the data we collected, the crime of sexual trafficking in Portugal is nowadays practised essentially by groups with a less "heavyweight" and almost unsophisticated structure, including the majority of cases involving the trafficking of Brazilian women, and less by organised criminal groups from Eastern Europe. Indeed, in these informal groups it is not unusual for the recruiters to be people who have great credibility in the eyes of their victims, since they are friends, family members, colleagues, etc.

Secondly, as we said above, as one of the predominant nationalities in the "sex market" in Portugal, many Brazilian women are linked to processes of social exclusion and precariousness which obviously can, at any given moment, lead to cases of sexual trafficking. Therefore, the fact that prostitution by Brazilian women is overwhelmingly seen as a "migrant work" choice may lead to cases of exploitation and trafficking being ignored. As a member of the criminal police force told us:

[...] We look at a Brazilian citizen who is operating freely in a particular place and maybe we don't immediately tend to see her as a victim of trafficking. That is not to say that she might not be, that issues concerning her origins before coming here might not make her a victim of trafficking. But the tendency is not to consider this. [...] So the women are immediately taken to the SEF [Aliens and Borders Service] to begin deportation procedures and the case is closed. This is a situation that clearly has to be corrected. On the other hand, what happens with this Moldavian and others from Eastern Europe is that we immediately look at them differently, because these are situations that clearly represent potential cases of trafficking. Not just pimping, not just illegal immigration, but potential trafficking situations. (P3, criminal police) ${ }^{16}$

As we can see, although the interpretation of the Palermo Protocol indicates that a woman's consent to prostitution does not mean she is not being exploited, there is no guarantee that when the agents of law and order actually apply this they are accepting this notion of "victim." Moreover, for various people we interviewed, the definition of "victim" in international legislation is still very close to the paradigmatic type of violent trafficking associated with organised criminal groups, whilst other situations escape scrutiny, such as those in which, in their opinion, Brazilian women become involved:

\footnotetext{
${ }^{16}$ Quoted from an interview transcribed in Santos et al., 2008.
} 
(...) Most of these Conventions are very much directed towards and focused on Eastern Europe. Nowadays we know that there are still organised groups associated with women who come from Eastern Europe, but the greater part of the "market" is ensured by Brazilian women, and this is a very specific reality that tends to evade the nature of the Conventions. (P6, magistrate $)^{17}$

Basically, as with other violent scenarios, it may be said that idealised types of "victims" are found in sex trafficking, with a clear distinction between "good" and "bad" victims. Following on from the work of Kelly and Regan (apud Aronowitz, 2001: 166), there are several levels of victimisation which correspond to different types of victims. The first level is associated with total coercion, when victims are kidnapped and there is no consent whatsoever. The second level refers to women deceived by promises of work that did not involve prostitution; in these cases, the women's consent was given on the basis of deceit. The third level involves a lesser degree of deception, when women know they will be working in the sex industry, but not in prostitution. Finally, the fourth level of victimisation, which is taken to be the least serious, concerns women who, prior to departure, already knew that they would be working as prostitutes, but did not know the extent to which they would be controlled, intimidated, indebted and exploited.

There is therefore a risk of producing a definition of trafficking that establishes hierarchies informed by moral values, which ultimately lead to the setting up of legal and/or practical barriers between women who deserve more help, women who deserve a relative amount of help and women who do not deserve any kind of help at all (Anderson and Davidson, 2002: 17).

Moreover, in this social construction of the "victim," women's self-determination should not be ignored by assuming that situations in which prostitution is exercised in accordance with a strategy defined by the woman herself, or in which she at least has some involvement, amount to trafficking. These women find it difficult to denounce the "network" in which they may be involved, and may not even want to be helped.

These different situations deserve careful consideration and reflection since, in addition to the paradigmatic "type" of sexual trafficking - the situation in which a woman has clearly been deceived and is forced to work as a prostitute for the first time against her will, through the use of coercion and force on arrival in Portugal - there is a whole range of situations which represent striking forms of abuse and destruction. There are many reasons

\footnotetext{
${ }^{17}$ Quoted from an interview transcribed in Santos et al., 2008.
} 
why these cases run the risk of going unnoticed: 1) there are many women who were prostitutes in their country of origin, and therefore, to a biased eye, it is difficult to see them as victims or as exploited; 2) there are women who knew they were coming to work as prostitutes and accepted the initial rules of the game; yet, despite maintaining the illusion that they live in a world they have created of their own free will, are frequently subjected to redefinitions and changes of rules by those in a position to take advantage of the previously mentioned vulnerabilities and invisibilities; 3 ) there are many immigrant women who chose to work as prostitutes in Portugal without losing control of the rules of the game. This fact per se, since it may correspond to the most visible face (and even the most common face of the phenomenon, according to some actors), may lead to a "sociological camouflaging" of situations in which women are victims of a dramatic reversal of the idea of sexual selfdetermination.

The boundaries between the two situations are subtle, since various forms of precariousness are involved here, creating a web in which women can easily fall into situations of sexual exploitation. Firstly, there is despair at their poverty in the country of origin - extreme situations of economic vulnerability and the inequalities between North and South tempt women into emigrating on the basis of vague proposals, leading them into situations of total ontological uncertainty, which are forged and exploited by the "sex industry." Secondly, there is the fact that prostitution is a phenomenon that takes place within the shadows of society, based on concealment and criminality and favouring all kinds of abuse of the most vulnerable actors involved in the phenomenon, the women who work as prostitutes and who are far away from their own country, with no social or other references. A third aspect concerns the fact that illegal immigration is a situation in which both promoters and victims (the immigrants and the exploited) share a fear of the state and the security forces. Finally, there is the fact that, due to its illegal nature, prostitution combined with pimping almost always operates in a climate of fear (even when trafficking is not involved) that is well justified by the very real likelihood of violent reprisals. As our study reveals, this culture of fear involves explicit threats to women's physical integrity and that of their family members, including those in their home country. But it also refers to the tacit climate of reprisals and violence which pervade the world of pimping, deterring any kind of denunciation of cases of sexual exploitation, not only by the women involved in trafficking 
situations but also by other women and other actors who are aware of, or strongly suspect, these facts.

Bearing in mind these complex networks and precarious contexts, the original reasons that lead women into trafficking situations cannot be ignored. Nor should the women's desires and expectations of finding a more stable and secure life in the host country, which still appear acceptable after the risks have been considered, be neglected.

\section{Final reflections}

In recent years, due to great international pressure in this area, various governments have sought to develop strategies to combat the trafficking of people in general and women in particular. The main strategy on the part of governments has been to create and reinforce appropriate legislation. This is, no doubt, fundamental, since despite the intensive production of conventions and international declarations, concern for the gravity of the trafficking of women for the purposes of sexual exploitation is still not reflected in the penal legislation of various countries. Furthermore, there are certain aspects referred to in the letter of the law and in its application which merit our concern, in the light of what we said above. Firstly, legislation tends to be specifically directed towards the criminal pursuit of trafficking without taking into account other fundamental legislation, such as the reinforcement of immigrant or labour rights, whether for national or other citizens. In this scenario, the risk of focusing on criminalising traffickers and neglecting the human rights of the people caught up in trafficking is high. For various authors, the laws which lead to trafficked women being immediately deported, or which make their stay in the host country dependent on giving evidence, are a particular concern.

One of the most striking effects is that, although people subjected to trafficking are called "victims" in various policies and laws, unless they become police informers and turn in their "traffickers," who may well be their friends, lovers, brothers, sisters or employers, they are treated as illegal immigrants, criminals or threats to national security. (Kempadoo, 2005a: 67)

Secondly, governments find themselves in a permanent limbo between protecting and promoting human rights and the desire to control borders. For some, the attention paid by governments to trafficking, in particular in Western Europe and North America, has focused more on issues of migration and control of migratory flows than on human rights, as the more restrictive immigration laws show. Ratna Kapur (2006: 109) even argues that the 
United Nations Protocol to Prevent, Suppress and Punish Trafficking in Persons, especially Women and Children, which reflects an unprecedented level of cooperation between various states and NGOs, is centred, above all, on migration and border control, and that, although it contains a set of important provisions, these are not binding, far less do they prevent women who are victims of trafficking from being criminalised or deported. Some NGOs and academics believe that these measures ultimately become more a part of the problem than a solution: not only do they not discourage trafficking but they also drive thousands of people who will not give up their migratory strategies into a clandestine existence.

Thirdly, and also with regard to human rights, the position of some authors who have been studying the question of the trafficking of women in Third World countries must be taken into consideration, together with their critique of the universal discourse of the human rights of trafficked women. The latter is directed towards the fact that the universality attributed to the declaration of human rights is nothing more than a Western perspective on the subject, whilst the South still does not to have a clear voice on its own problems, and that specific aspects of common problems are not taken into consideration (e.g. Santos, 2004; Kapur, 2006). From the outset, when speaking of the human rights of trafficked women it is necessary to understand that these women differ and come from culturally and socially diverse regions - in other words, attention needs to be paid to cultural differences, avoiding universalist readings. Whilst it is fundamental that gender should not be forgotten in the issue of sex trafficking, it is necessary not to resort to an essentialism which views women as a homogenous category, not the least because when causes are homogenised, the same can easily happen to solutions. Perhaps for this reason, despite the multiple responses of the United Nations and various governments to the problem of violence against women in the past decade, rape, enforced prostitution and trafficking still persist and are spreading.

Fourthly, an in-depth debate is necessary on the subject of consent. Sexual slavery and the forms of extreme exploitation to which female prostitutes may be subjected undoubtedly represent situations of suffering. Yet even voluntary consent merits analysis. The wretchedness and poverty underlying such decisions should be confronted. Voluntary acts usually occur on an individual level, but are the expression of collective acts of social injustice. Society creates situations in which a young man or woman has no other chance of 
earning a wage for themselves or their family except through prostitution. This puts society as a whole under debate, namely a capitalist society which creates these forms of constraint within which voluntary acts are possible, and also leads us to reflect on the entire ethical and moral context within which this issue is debated. This discussion should not be limited to the causes of trafficking, but also to the solutions.

Fifthly, we should take into consideration the fact that few governments have programmes that enable trafficked women to make real choices about their future deciding to return to their own country or, alternatively, remaining in the country of their destination - far less do they prepare them for their return home or help them once they are back in their country of origin (Corrin, 2004: 181).

In addition, in several countries the treatment of women who are victims of trafficking, whether within the context of normative provisions or their application, is often influenced by moral concepts. Because of the strong social stigma attached to female prostitutes, their civil and human rights are frequently violated (Anderson and Davidson, 2002: 40). Only in a few countries are women who work as prostitutes effectively protected by the law and, as we have seen in the case of Portugal, the stereotypes and preconceptions relating to prostitution and immigrant women of particular nationalities may mean that the law is not enforced.

We believe it is fundamental that the law and, basically, any policy designed to combat the trafficking of women for the purposes of sexual exploitation, should clearly aim to produce transformatory measures directed towards strengthening individual and collective awareness of these women, fighting the various forms of oppression which seek to subordinate them, whilst not, however, reducing them to the category of passive victims or allowing them to be stigmatised or excluded. Effective help for women who are the victims of trafficking implies fighting our own preconceptions and stereotypes. It presupposes the definition of an aid policy that does not exert any control over the choices these women make and respects their human rights in different cultural contexts, without involving a universalist discourse that prevents us from understanding the political, social and cultural relations underlying their choices once they arrive in the country of their destination. In our view, a progressive attitude in this area can only be an attitude which strengthens collective awareness of these women and enables them to escape the subhuman conditions in which 
they find themselves, by constructing their citizenship. This is the greatest challenge which sex trafficking presents to law.

Translated by Sheena Caldwell

Revised by Teresa Tavares

\section{References}

Anderson, Bridget; Davidson, Julia O'Connell (2002), Trafficking - A Demand Led Problem. Sweden: Save The Children.

Aronowitz, Alexis A. (2001), "Smuggling and Trafficking in Human Beings: The phenomenon, the markets that drive it and the organisations that promote it," European Journal on Criminal Policy and Research, 9, 163-195.

Barry, Kathleen (1995), The Prostitution of Sexuality. New York: New York University Press.

Corrin, Chris (2004), "Traffic in Women in War and Peace: Mapping experiences in Southeast Europe," Journal of Contemporary European Studies, 12(2), 177-192.

Engle, Lauren B. (2004), The World in Motion. Short Essays on Migration and Gender. Geneva: International Organization for Migration.

Ehrenreich, Barbara; Hochschild, Arlie Russell (2002), Global Woman: Nannies, Maids and Sex Workers in the New Economy. London: Granta Books.

Farr, Kathryn (2005), Sex Trafficking: The Global Market in Women and Children. New York: Worth Publishers.

Gaspard, Françoise (1998), "Invísiveis, diabolizadas, instrumentalizadas: figuras de mulheres migrantes e das suas filhas na Europa," Revista Crítica de Ciências Sociais, 50, 83-101.

Gilroy, Paul (1992), The Black Atlantic: Modernity and Double Consciousness. Cambridge, Mass.: Harvard University Press.

Jeffreys, Sheila (1999), "Globalizing Sexual Exploitation: Sex tourism and the traffic in women," Leisure Studies, 18, 179-196.

Kapur, Ratna (2005) "Cross-border Movements and the Law: Renegotiating the boundaries of difference," in Kamala Kempadoo (ed.), Trafficking and Prostitution Reconsidered. New Perspectives on Migration, Sex Work, and Human Rights. Boulder, Colorado: Paradigm Publishers.

Kapur, Ratna (2006), "Revisioning the Role of Law in Women's Human Rights Struggles," in Saladin Meckled-Garcia \& Basak Cali (eds.), The Legalization of Human Rights: Multidisciplinary Perspectives on Human Rights and Human Rights Law. London: Routledge.

Kempadoo, Kamala (2005a), "Mudando o debate sobre o tráfico de mulheres," Cadernos Pagu, 25 (July-December), 55-78.

Kempadoo, Kamala (2005b), "From Moral Panic to Global Justice: Changing perspectives on trafficking," in Kamala Kempadoo (ed.), Trafficking and Prostitution Reconsidered. New Perspectives on Migration, Sex Work, and Human Rights. Boulder, Colorado: Paradigm Publishers.

Kempadoo, Kamala; Doezema, Jo (eds.) (1998), Global Sex Workers: Rights, Resistance, and Redefinition. New York: Routledge. 
Lopes, Ana (2006), Trabalhadores do sexo uni-vos! Organização laboral na indústria do sexo. Lisbon: D. Quixote.

Mignolo, Walter D. (2000), Local Histories/Global Designs: Coloniality, Subaltern Knowledges, and Border Thinking. Princeton: Princeton University Press.

Pickup, Francine (1998), "More words but no action? Forced migration and trafficking of women," in Gender and Development, 6(1), 44-51.

Regulska, Joanna (1998), “A nova 'Outra' mulher europeia," Revista Crítica de Ciências Sociais, 50, 47-71.

Ribeiro, Manuela et al. (2005), Prostituição abrigada em clubes (zonas fronteiriças do Minho e Trásos-Montes): práticas, riscos e saúde. Colecção Estudos de Género. Lisboa: CIDM.

Rodrigues, Anabela (1999), in Figueiredo Dias (ed.), Comentário Conimbricense do Código Penal Tomo I. Coimbra: Coimbra Editora.

Santos, Boaventura de Sousa (2000), A crítica da razão indolente: contra o desperdício da experiência. Porto: Edições Afrontamento.

Santos, Boaventura de Sousa (2004), "Por uma concepção multicultural dos direitos humanos," in Boaventura de Sousa Santos (org.), Reconhecer para libertar: os caminhos do cosmopolitismo cultural. Porto: Afrontamento.

Santos, Boaventura de Sousa (2007), "Para além do pensamento abissal: das linhas globais a uma ecologia de saberes," Revista Crítica de Ciências Sociais, 78, 3-46.

Santos, Boaventura de Sousa; Gomes, Conceição; Duarte, Madalena; Baganha, Maria (2008), Tráfico de mulheres em Portugal para fins de exploração sexual. Colecção Estudos de Género. Porto: CIG.

Sullivan, Barbara (2003), "Feminism and New International Law," International Feminist Journal of Politics, 5(1), 67-91

Techio, Kachia (2006), "Conhecimentos de alterne: a outra diáspora das imigrantes brasileiras," Socius Working Papers, 2, 1-22.

Vaz Patto, Pedro (2007), "O crime de tráfico de pessoas no Código Penal revisto. Análise de algumas questões." Paper presented at the Meeting on the Revision of the Criminal Code [Jornadas sobre a Revisão do Código Penal] - 27 and 28 September, CEJ, Lisbon. 